3. Данилова I. О. Визнання одностатевих шлюбів в Україні: бути чи не бути? / I. О. Данилова. // «Young Scientist». - 2017. - № 11. С. 869-871.

4. Миронець О. М. Легалізація одностатевих шлюбів в Україні / О. М. Миронець, Т. С. Ярошенко, А. В. Яценко. // Международный научный журнал «Интернаука». - 2017. - № 16. - С. 56-59.

5. Конституція Польської Республіки (з передмовою Володимира Шаповала) / В.М. Шаповал - К.: Москаленко О.М., 2018. - 82 с.

6. Ткаченко В. Колізійні питання реалізації права на шлюб у міжнародному приватному праві/ Віта Ткаченко. // Підприємництво, господарство і право. - 2020. - № 6. - С. 282-286.

7. Конституція України // Відомості Верховної Ради України (BBP). 1996. № 1. C. 1.

DOI https://doi.org/10.30525/978-9934-26-040-7-9

\title{
ПРАВОВІ ЦІННОСТІ: ЗАГАЛЬНОТЕОРЕТИЧНИЙ ОГЛЯД
}

\author{
Назаренко О. А. \\ кандидат юридичних наук, \\ старший викладач кафедри теорї держави та права \\ Національної академії внутрішніх справ \\ м. Київ, Украӥна
}

Звертаючи увагу на всі політичні та загалом соціальні проблеми $\mathrm{i}$ кризи, які відбуваються у сучасному світі, все дедалі більше необхідними стають існуючі правові цінності, які продовжують нагадувати про те, що незважаючи на ніякі обставини не потрібно нехтувати їх всебічною та загальносоціальною значимістю. Крім того, потрібно завжди пам'ятати і піклуватись про пріоритет збереження загальних правових благ з метою забезпечення не тільки публічних, але й приватних інтересів громадськості. Саме свобода, як невід'ємна правова цінність у житті людини, що надає можливість для її власної самореалізації та самовизначеності повинна залишатись непорушною гарантією суспільного розвитку. Ідеї збереження рівності та справедливості дбають про уникнення безвихідності для вирішення проблем, які регулюються правом та покликані впорядковувати 
суспільні відносини. Оскільки, поряд з ними діють законність та правопорядок, які завжди мають стояти на сторожі інтересів, прав та свобод людини і громадянина, що мають залишатись непорушними за будьяких умов. Саме за допомогою закріплених у положеннях чинного законодавства норм права, власне й регулюється діяльність держави та громадянського суспільства, що потребують збереження цілісності всіх існуючих елементів правових цінностей, а також особливостей їх проявів в безперервному та швидкоплинному процесі життєдіяльності людини.

Так, в сучасній юридичній науці панує численна кількість можливих підходів до розуміння правових цінностей, що відображаються у різних наукових джерелах. Зокрема, як зазначає С. В. Михайлов під цінностями у праві, або власне під правовими цінностями необхідно розуміти ті цінності, які правом інтегровані, а цінності права - це цінності, які уособлюються правом повністю або частково. До таких цінностей належить свобода, справедливість, рівність, взаємодопомога, тобто цінності, сфера дії якої знаходиться на перетині права та моралі. Саме тому в межах ціннісного підходу можна виділити з певною долею умовностей, певні блоки правових цінностей: «абсолютних цінностей» - свободу, справедливість, рівність, правопорядок, демократію; «основні цінності» - життя, здоров'я, честь, гідність; «спеціальні цінності», що так само як і попередні опосередковані з його правами, охоплюють також безпеку, приватну власність, свободу віросповідань [1, с. 10]. У свою чергу Н. С. Цинцадзе вважає, що такі цінності, як свобода, рівність і справедливість являються соціальними, а не правовими. До головних правових цінностей необхідно віднести ідеї концепти як право, галузь права, інститут права, правові принципи, закон, законність правопорядок, правова стабільність та ефективність права. Також, доцільно з позиції теорії права розділити їх на цінності приватного та публічного права [2, с. 193]. Підходи до визначення правових цінностей різняться перш за все своїми поглядами на змістове наповнення цього поняття. Кожен з висвітлених елементів в тій чи іншій позиції поєднує у собі різноманітні характерні для них особливості, які власне і найбільш повно прагнуть відобразити їх сутність.

Натомість А. О. Маргушина зосереджує свою увагу на тому, що правові цінності без правового порядку є безцільними, а правовий порядок без ціннісного наповнення бездіяльний, оскільки не можна вважати правою цінністю форму поведінки, яка незабезпечена державним примусом або його потенціалом, який реалізується як правило, в установленій юридичній формі [3, с. 17]. А. М. Бабенко 
вважає, що становлення правових цінностей представляє собою результат процесу відчуження влади від суспільства, тобто виникнення публічної влади, яка не співпадає з суспільством. Систему правових цінностей доповнює система цінностей політичних. Під правом розуміється явище загальнообов' язкового нормативного регулювання у всеохоплюючих політичних організаціях [4, с. 3-4]. У зв'язку з чим варто зазначити, що А. О. Маргушина говорить про те, що правові цінності у виявленій або завуальованій формі зберігаються в політичних деклараціях, виявляючи вплив на процеси затвердження рішень, а також забезпечують основу правового виховання, знаходять вплив на вибір способів і засобів запобігання та вирішення правових конфліктів та колізій [3, с. 18]. Сама ж по собі сутність права виражається в двох основних проявах або функціях: з однієї сторони, воно представляє, відводить особі провідну сферу свободи; $з$ іншої сторони, воно обмежує цю сферу цілим рядом приписів, зокрема рядом обов'язкових правил [5, с. 233]. Правові цінності представляють собою багатогранне явище, яке зосереджує в собі цілий комплекс різноманітних елементів, які приймають активну участь в реальному процесі суспільного життя. Якщо поглянути на вище висвітлені положення можна побачити, що досить складно навести їх єдиний та вичерпний перелік. Кожен 3 них представляє собою унікальне значення для повноцінного функціонування політичної системи суспільства. Норма права сама по собі є важливою цінністю, яка доповнює собою перелік цінностей вже викладених в наукових підходах, зокрема втілюючись в життя у вигляді законності та правопорядку.

На думку В. В. Самохвалова не саме наявне законодавство складає зміст законності, а таке законодавство, що адекватно втілює правові принципи, нагальні потреби та інтереси людини, загальнолюдські ідеали та цінності, ідеї доцільності та справедливості і об'єктивні тенденції соціального прогресу [6, с. 39]. Поряд з цим можна побачити, що правовий порядок представляє собою такий стан практичного упорядкування суспільних відносин, яке виражає безумовне виконання вимог об'єктивно значимої законності. Правопорядок, як природній результат законності, характеризує собою рівень реалізації ії вимог [7, с. 82]. Взаємозв'язок цих двох правових цінностей приймає безпосередню участь у практичній сфері життя людини, а саме зосереджує увагу на тих моментах з якими суспільство зустрічається в процесі життя та від яких залежить якісний стан правової поведінки.

Таким чином, можна підвести підсумки, що стосується питання пов'язаного з загальнотеоретичним оглядом правових цінностей, які на сьогоднішній день відіграють особливе значення для демократичної 44 
інтеграції держави та розвитку її суспільства. Як вже зазначалось, серед численної кількості цінностей, досить важко виокремити єдиний вичерпний перелік. Досягнути такого уніфікованого підходу складно саме через те, що вони є багатогранними та унікальними за своєю природою, а також можуть розширюватись у кількості. В незалежності від того про який з видів правових цінностей йде мова (справедливість, свобода, рівність, демократія та інші) визначається його суспільна значимість. Сама ж держава, як особливий суб'єкт політичної системи приймаючи участь у правотворчому процесі представляє собою не просто важливу цінність, але й ще крім того покликана охороняти та захищати всі інші поряд існуючі. Особливої уваги в контексті цього заслуговує цінність високого демократичного розвитку, яка буде сприяти подальшому вільному становленню та розвитку правових концепцій в інтересах людини. Такий характер влади зможе реалізовувати свою діяльність 3 урахуванням тих ідей, які містяться у найбільш відомих правових цінностях, що будуть формуватися в процесі та умовах настання новітнього часу. Оскільки метою сучасного політичного розвитку в подальшому перш за все має бути розповсюдження всіх відомих соціальних інтересів (економічних, культурних, духовних, політичних та інших) через особливо важливу призму пріоритетності прав та свобод людини і громадянина.

\section{Література:}

1. Михайлов С. В. Правовые ценности: теоретико-правовой аспект : автреф. дис. ... канд. юрид. наук : 12.00.01. Ростов-на-Дону, 2011. 28 с.

2. Цинцадзе Н. С. Классификация и иерархия правовых ценностей в теории права. Вестник Тамбовского университета. Тамбов, 2014. Вып. 2 (130). С. 189-195

3. Маргушина А. А. Правовой порядок и правовые ценности : институционально-правовой анализ : автреф. дис. ... канд. юрид. наук : 12.00.01. Краснодар, 2013. 27 с.

4. Бабенко А. Н. Государство и правовые ценности. Вестник Южно-Уральского государственного университета. Челябинск, 2007. Вып. 10. С. 3-7

5. Філософія та енциклопедія права в Університеті Святого Володимира / за ред.: І. С. Гриценка. Київ : Либідь, 2011. Кн. 2. 448 с.

6. Енциклопедія законодавства / за заг. ред. В. П. Самохвалова. Київ : Український центр духовної культури, 2003. 228 с.

7. Болдырев С. Н., Працко Г. С. Право, правовые законы и правопорядок. Юристь-Проповедь. 2018. № 4 (87). С. 81-86 